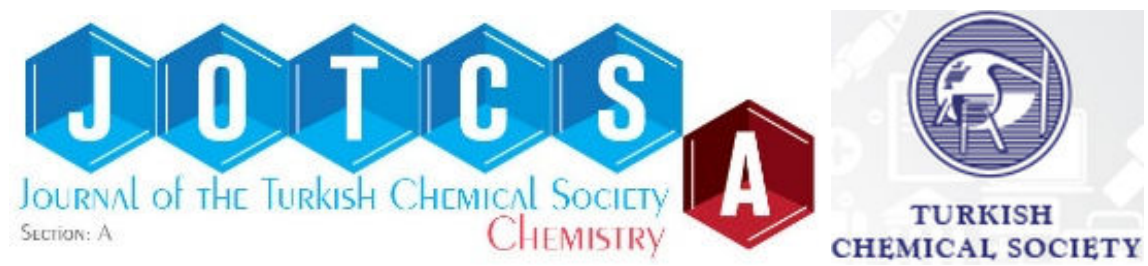

\title{
Synthesis of Copper Nanoparticles Using a Different Method: Determination of Their Antioxidant and Antimicrobial Activity
}

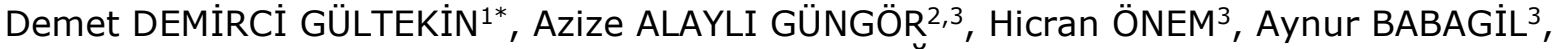 \\ Hayrunnisa NADAROĞLU ${ }^{3,4}$
}
${ }^{1}$ Ataturk University, Aşkale Vocational Collage, Department of Metallurgical Program, 25500, Aşkale, Erzurum, TURKEY
${ }^{2}$ Ataturk University, Erzurum Vocational Collage, Department of Chemical Technology, 25240 Erzurum, TURKEY
${ }^{3}$ Ataturk University, Faculty of Engineering, Department of Nano-Science and Nano- Engineering, 25240 Erzurum, TURKEY
${ }^{4}$ Ataturk University, Erzurum Vocational Collage, Department of Food Technology, 25240 Erzurum, TURKEY

\begin{abstract}
The aim of this study was to obtain copper oxide nanoparticles (CuO NPs) through a method of green synthesis that involves using peroxidase enzymes that are partly purified from fig leaves (Ficus carica). CuO NPs were successfully synthesized using the green synthesis method in the experiments performed. Ultraviolet-visible (UV-Vis) spectrophotometry of the characteristics of the acquired CuO NPs was performed with scanning electron microscopy (SEM) and X-ray diffraction (XRD). The optimum activation temperature for green synthesis was observed to be in $30 \mathrm{~min}, \mathrm{pH}: 8$, at $25{ }^{\circ} \mathrm{C}$ and in the concentration of $1 \mathrm{mM} \mathrm{CuCl}$. By using peroxidase enzymes with green synthesis, it was found that the results of the SEM and XRD measurements that acquired the CuO NPs were in the size of 50-120 nm. Afterwards, the antioxidant and antibacterial activities of these nanoparticles were measured, and it was understood from the obtained results that CuO NPs have both antioxidant and antimicrobial activities.
\end{abstract}

Keywords: Copper nanoparticles; green synthesis; peroxidase.

Submitted: July 22, 2016. Revised: September 24, 2016. Accepted: October 20, 2016.

Cite this: Demirci Gültekin D, Alaylı Güngör A, Önem H, Babagil A, Nadaroğlu H. Synthesis of Copper Nanoparticles Using a Different Method: Determination of Their Antioxidant and Antimicrobial Activity. JOTCSA. 2016;3(3):623-36.

DOI: To be assigned.

*Corresponding author. E-mail: dedemirci@yahoo.com. 
Demirci Gültekin et al., JOTCSA. 2016; 3(3): 623-636.

\section{INTRODUCTION}

Nowadays, the subject of nanotechnology encompasses many fields, including the environment, water treatment, chemical production, containers and converters of solar power, antimicrobial agents, textiles, dyes, health, and even defense [1-3]. The research indicates that nanotechnology is engaging even more with these fields as time passes.

The characteristics of a material can change significantly when that material is nano-sized. The differences in the characteristics of the substance are the result of quantum size effects. Metal nanoparticles, in particular, show very different optical, thermal, chemical, and conductivity characteristics compared to normal metal particles. Nano-sized metals and metal oxides are able to be used in many areas because of the characteristics they assume.

Green synthesis has become one of the most preferred applications in various fields, including chemistry, because of its eco-friendly approach. With the application of green synthesis to nanochemistry, another area of study had emerged that has gained increasing value: Green nano synthesis. Green nano synthesis allows for a nano material to be synthesized in a way that is friendly to both humans and to the environment. In this synthetic method, toxic chemicals that are damaging to nature are avoided and, instead, less-harmful substitutes are used. The reaction environment used in green nano synthesis can be a tissue, cell, organism, extract, enzyme, carbohydrate, lipid, or protein produced from a lipid. Three of these types of green synthesis environments are commonly used. The first of these is enzymes, which are able to catalyze a wide range of chemical reactions, resulting in their use in green nano synthesis in recent years. In addition, microorganisms (such as bacteria, yeast and mold) and plant and animal extracts are commonly used to synthesize nanoparticles in green synthesis. These three reaction environments are most common because they allow for eco-friendly, non-toxic, costefficient and mild conditions [6-9]. These are not, however, the only reaction environments used in green synthesis. The synthesis of silver nanoparticles (AgNPs) has been achieved by some research groups using Nephelium lappaceum L. and Plectranthus amboinicus leaf extracts. Another research group has synthesized gold nanoparticles (Au NPs) using a plant extracts in a similar way [3-4].

Copper nanoparticles, which have been a focus of interest since the end of $20^{\text {th }}$ century due to their catalytic, optical, and electrical features, are widely used in the electricity sector because of their conductivity features; in chemistry, they are used as a lubricator and catalyst [10-12]. Since the copper (II) oxide nanoparticle (CUO NP) is semi-conductive, it is often used in catalysts, gas sensors, and photovoltaic cells. Due to its electronic and magnetic characteristics, CuO has been used as one of the basic components of high temperature superconductive substances, causing it to become very widely used [13]. Etefagh et al. designed a sensor founded on 
Demirci Gültekin et al., JOTCSA. 2016; 3(3): 623-636.

nanoparticles and nanolayers of $\mathrm{CuO}$. CuO NPs were produced using the sol-gel technique, and their nanolayers were prepared using spray pyrolysis [14]. Phiwdang's research group investigated the effect of starting precursors on structural properties of $\mathrm{CuO}$ nanostructures synthesized via the precipitation technique [15]. Khashan et al. discovered the consequence of altering the ablation time and laser energy on produced CuO NPs using laser ablation in liquid. The antibacterial activity of these CuO NPs with or without amoxicillin on cultures of gramnegative and gram-positive bacteria was also presented [16].

Recently, fig extracts have become another preferred reaction environment for green nano synthesis. For instance, $\mathrm{Hu}$ (2015) achieved a synthesis of tin dioxide $\left(\mathrm{SnO}_{2}\right)$ using the extract obtained from fig leaves, applying the synthesized compound to the electrochemical detection of mercuric $\mathrm{Hg}$ (II) [3]. In another field, Singh and Bhakat studied the nano technological applications of gold and silver nanoparticles after synthesizing both with the leaves and bark of a fig tree [6].

Peroxidases are known as (EC.1.11.1.7) oxidoreductases. Usually, there is an iron porphyrin ring on their structures, and they catalyze redox reactions such as electron transfer and oxygen exits from a donor such as hydrogen peroxide $\left(\mathrm{H}_{2} \mathrm{O}_{2}\right)$. The peroxidase enzyme (POX) has been purified so far in plants such as turnips, soy beans, tomatoes, potatoes, carrots, wheat, pears, apricots, bananas, dates, and strawberries [17].

In this study, we used POX that has been partly purified from the leaves of a fig plant. CuO NPs were synthesized using the purified enzymes. The characterization of the obtained CuO NPs was performed using an ultraviolet-visible (UV-VIS) spectrophotometer, X-ray diffraction (XRD), scanning electron microscopy (SEM) and Fourier transform infrared spectroscopy (FTIR). The antioxidant and antimicrobial features of the obtained CuO NPs were discovered.

\section{EXPERIMENTAL SECTION}

\section{Chemicals and Reagents}

Copper(II) chloride $\left(\mathrm{CuCl}_{2}\right)$, 2,2'-azino-bis (3-ethylbenzthiazol-6-sulfonic acid) (ABTS), neocuproine (2,9-dimethyl-1,10-phenanthroline), riboflavin, methionine, nitroblue tetrazolium (NBT), 1,1-diphenyl-2-picryl-hydrazyl (DPPH), 3-(2-pyridyl)-5,6-bis (4-phenyl-sulfonic acid) 1,2,4-triazine (ferrozine), $\alpha$-tocopherol, linoleic acid, gallic acid, quercetin, Folin-Ciocalteu and trichloroacetic acid (TCA) was purchased from Sigma-Aldrich GmbH (Sternhe I Germany). All other chemicals were obtained from Merck.

\section{Preparation of Plant Samples}

The fig plant (Ficus carica) used in the study was collected from Sakarya, Turkey, and it was identified with the help of taxonomists. The plant was cut into small (50 g) pieces. The pieces 
Demirci Gültekin et al., JOTCSA. 2016; 3(3): 623-636.

RESEARCH ARTICLE

were thoroughly shattered to form a homogeneous mixture in a blender, along with a $250 \mathrm{~mL}$, $10 \mathrm{mM}$ sodium phosphate buffer $(\mathrm{pH}: 6.0)$. The mixture was centrifuged at $5000 \mathrm{~g}$ for $10 \mathrm{~min}$, and the supernatant was used for enzyme purification [18].

\section{Partial Purification of the POX with Ammonium Sulfate Precipitation}

The upper solution of the fig plant in sodium phosphate buffer was saturated from $60 \%$ to $80 \%$ with ammonium sulfate; then, the POX was precipitated by being centrifuged at $7000 \mathrm{~g}$ for 30 min. The obtained precipitate was dissolved in the $5 \mathrm{~mL}, 10 \mathrm{mM}$ sodium phosphate buffer $(\mathrm{pH}: 6.0)$ and was incubated at $4^{\circ} \mathrm{C}$ for further analysis [18].

\section{POX Activity Test}

The peroxidase activity assay was measured using a substrate of $1 \mathrm{mM} \mathrm{2,2'-azino-bis(3-}$ ethylbenzthiazoline-sulfonic acid) diammonium salt (ABST) prepared in a 0,1 M phosphate buffer $(\mathrm{pH}: 6.0)$. The changes in absorbance were monitored at $412 \mathrm{~nm}$ using a UV-Vis spectrophotometer at 1 -min intervals for $3 \min [18]$.

\section{Synthesis of CuO NPs}

An amount of $300 \mu \mathrm{g} / \mathrm{mL}$ of purified POX from the fig plant was added to a sample of copper(II) chloride solution $\left(\mathrm{CuCl}_{2}\right)(2.9 \mathrm{~mL}, 10 \mathrm{mM})$ and incubated in a closed space for 4 hours. The solution became blue in color and was cloudy, indicating the presence of CuO NPs. Then, water was removed with the help of an evaporator, and the synthesized CuO NPs were dried at $70^{\circ} \mathrm{C}$ for 24 hours [18].

\section{Characterization of CuO NPs}

Synthesized CuO NPs were characterized by being scanned with a UV-VIS spectrophotometer (PG Instrument T80 UV-VIS spectrophotometer, UK) at a range of 200-1000 nm. Determination of the topography of the CuO NPs was performed using a scanning electron microscope (Sigma 300, SEM Zeiss, Germany). In addition, XRD analysis (PANalytical, Empyrean, Netherlands) was performed at DAYTAM (Eastern Anatolian High Technology Applications and Research Center) to determine the size of the CuO NPs.

\section{Optimization of Green Synthesis Reaction Medium}

Optimum contact time: To determine the optimum contact time, samples were spectrophotometrically measured between 0 and $240 \mathrm{~min}$ at 3-min intervals.

Determination of optimum pH: Synthesis of the CuO NPs was performed at $\mathrm{pH} 2-3$, an acetate buffer at $\mathrm{pH} 4-6$, a phosphate buffer at $\mathrm{pH} 7-8$, and a carbonate buffer at $\mathrm{pH} 9-11$. The values of absorbance were measured by UV-Vis spectrophotometer. The $\mathrm{pH}$ was adjusted using $0,1 \mathrm{~N} \mathrm{HCI}$ and $0,1 \mathrm{~N} \mathrm{NaOH}$. 
Demirci Gültekin et al., JOTCSA. 2016; 3(3): 623-636.

RESEARCH ARTICLE

Determination of optimum temperature: Synthesis of the CuO NPs was carried out separately from $10^{\circ} \mathrm{C}$ to $90^{\circ} \mathrm{C}$, respectively, and the changes in absorbance in the samples was measured by UV-VIS spectrophotometer.

Determination of optimum concentration of metal ion: Synthesis of the CuO NPS was performed using a copper(II) chloride solution at $0.5 \mathrm{mM}, 1 \mathrm{mM}, 3 \mathrm{mM}, 5 \mathrm{mM}$ and $7 \mathrm{mM}$, and the absorbance of the samples was measured by a UV-Vis spectrophotometer $(350 \mathrm{~nm})$.

\section{Antimicrobial Activity of Copper Nanoparticles}

Antagonistic activity of the synthesized CuO NPs was determined against Pediococcus acidilactici. A sterile Potato Dextrose Agar (PDA-Oxoid) nutrient medium was prepared and sterilized overnight. The bacterium was studied in three replications, and the average inhibition zone created by the bio-agent was identified with the help of the values obtained [19-20]. In addition, the minimum inhibitory concentration (MIC), defined as the lowest concentration of material that inhibits the growth of a bacterium, was determined as based on batch cultures containing varying concentrations of CuO NPs.

\section{RESULTS AND DISCUSSION}

\section{Synthesis of copper nanoparticles}

$300 \mu \mathrm{g} / \mathrm{mL}$ of purified peroxidase enzyme was added in sample of copper(II) chloride solution $\mathrm{CuCl}_{2},(10 \mathrm{mM})$ and incubated in a closed space for 3 hours. The solution was becoming blue to intense blue, which indicates the presence of copper nanoparticles. Then, water was removed with the help of an evaporator and copper nanoparticles were synthesized and they were dried at $65{ }^{\circ} \mathrm{C}$ for 48 hours (Figure 1) [21].

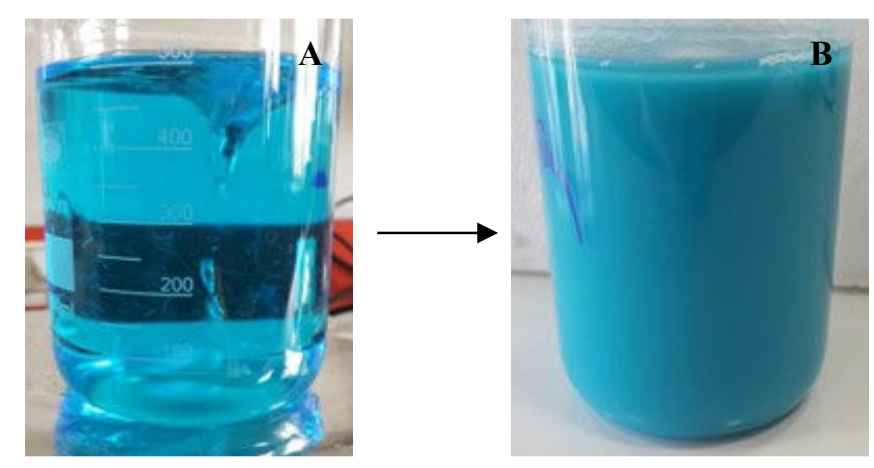

Figure 1. Reaction of green synthesis of copper nanoparticules (A): Before reaction, (B) After reaction.

\section{Chemical properties of CuO NPs synthesis}

Contact time was determined to be 30 min., optimum pH was determined as 8.0, optimum temperature was $25{ }^{\circ} \mathrm{C}$, and metal ion concentration was determined as $1 \mathrm{mM}$ for the purpose of optimization of synthesized CuO nanoparticles using a UV-Vis spectrophotometer at $350 \mathrm{~nm}$. 


\section{XRD studies}

Copper nanoparticles' XRD which was produced in its peroxidase enzyme catalyst and its crystallographic analysis are given in Figure 2. Characteristic peaks which belong to XRD spectrum in its at $2 \theta=19.86^{\circ}, 24.55^{\circ}, 58.71^{\circ}, 75.22^{\circ}$ that can be indexed at (111), (200), (220) facets which agree with the values reported for face centered cubic (fcc)

copper nanocrystals (Figure 2).

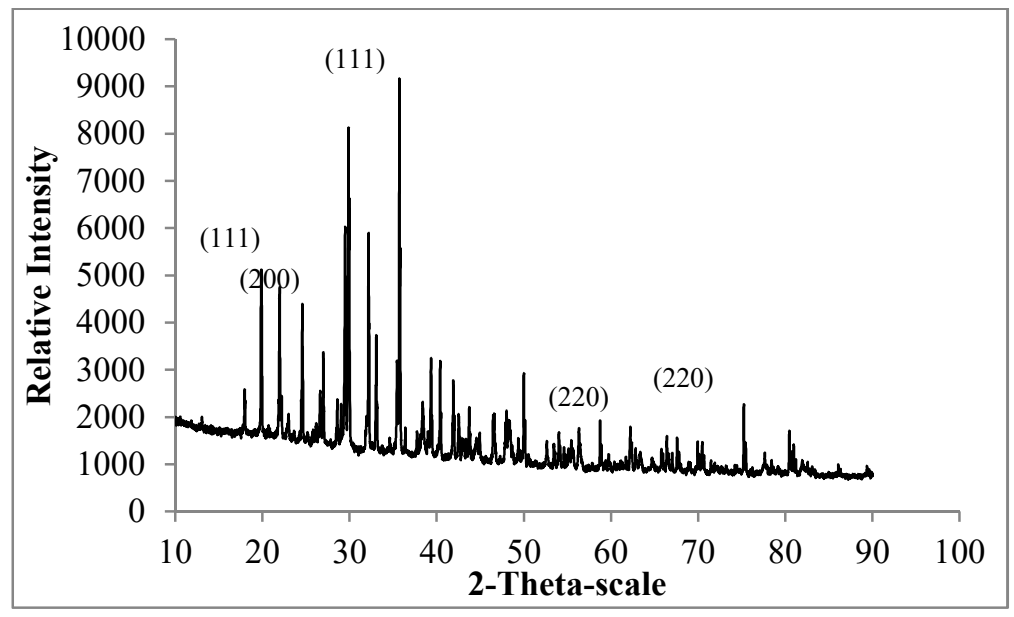

Figure 2. X-ray diffraction pattern of the synthesis of copper nanoparticles using peroxidase enzyme from Fig (Ficus Carica).

\section{Surface characterization of CuO NPs}

Chemical and mineralogical compositions of synthesized green copper NPs were determined by scanning electron microscopy (SEM), which was used to examine the surface of the adsorbent. Images of CuO NPs were magnified 10000 times by Zeiss, Active area $10 \mathrm{~mm}^{2}$, (Figure 3). It was observed from figure that most of the CuO NPs were spherical in shape. Figure 3 showed a well dispersed CuO NPs had identified in the sizes range 50-120 nm. In CuO nano particles, which were synthesized by using many plant extracts were identified as mostly in spherical from and between 5-200 $\mathrm{nm}$ in sizes [21]. 


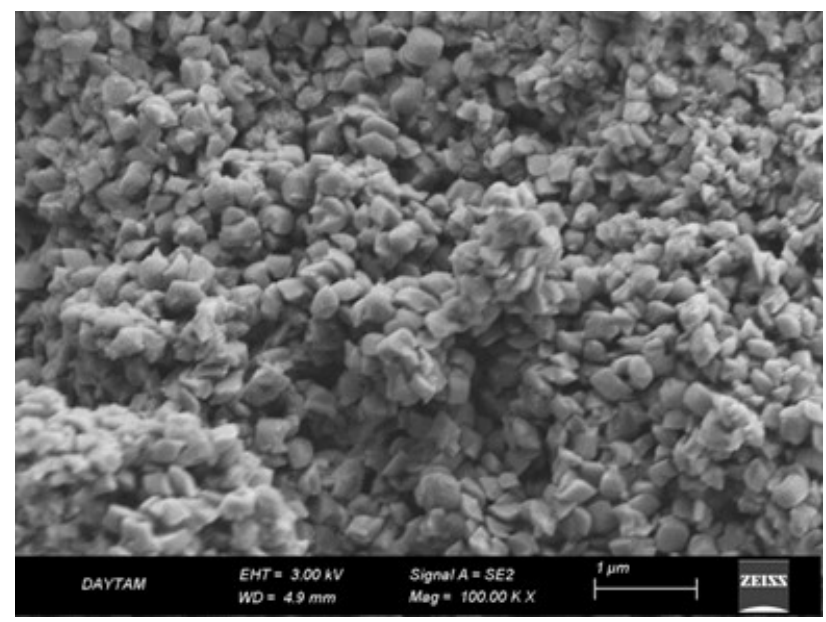

Figure 3. SEM image of the synthesized copper nanoparticles.

\section{Antioxidant activity of CuO NPs}

The $\mathbf{F e}^{3+}-\mathbf{F e}^{2+}$ reducing (FRAP) activity: In $\mathrm{Fe}^{3+}-\mathrm{Fe}^{2+}$ reducing method, antioxidants give electron and show activity. It is found that the potential of synthesized copper NPs to reduce ferric ions $\left(\mathrm{Fe}^{3+}\right)$ to ferrous ions $\left(\mathrm{Fe}^{2+}\right)$ directly increase in directly proportional with concentration. The reduction was monitored by measuring the change of absorbance at $593 \mathrm{~nm}$. (Figure 4).

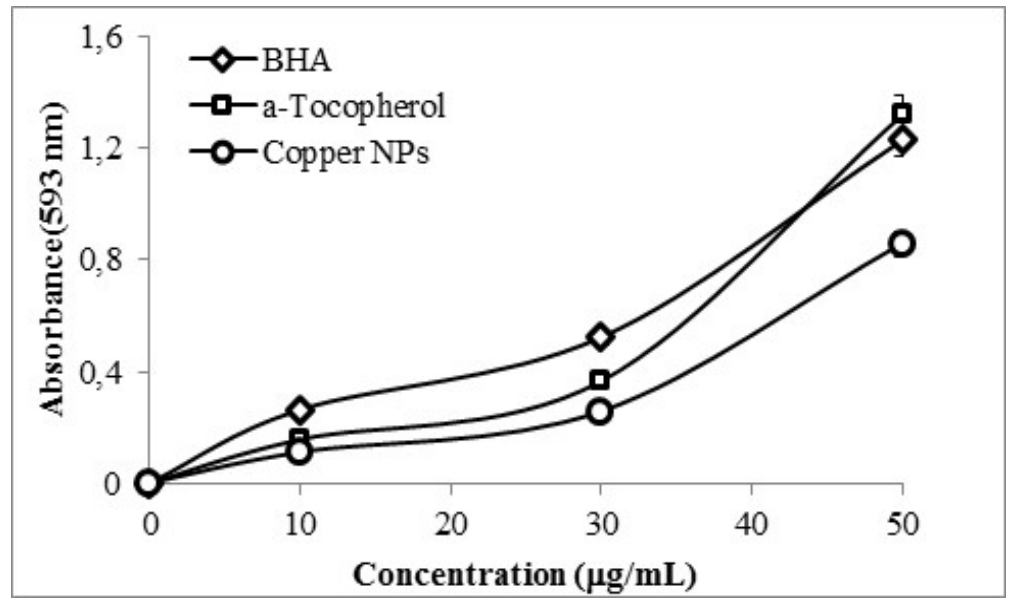

Figure 4. The $\mathrm{Fe}^{3+}-\mathrm{Fe}^{2+}$ reducing activity of different concentrations $(10-30 \mu \mathrm{g} / \mathrm{mL})$ of water extracts, alcohol extracts, $\alpha$-tocopherol, and BHA.

\section{The $\mathrm{Cu}^{2+}-\mathrm{Cu}^{+}$reducing activity}

Another method to determine reducing capacity is CUPRAC method. Cupric ions $\left(\mathrm{Cu}^{2+}\right)$ reducing capacity of copper NPs is determined with spectrophotometric method having different concentrations (10-30 $\mathrm{g} / \mathrm{mL}$ ) of copper NPs. Reducing capacity of $\left(\mathrm{Cu}^{2+}\right)$ by synthesized copper NPs are compared with BHT and $\alpha$-tocopherol as standard antioxidants and were shown in Figure 
5. In $50 \mu \mathrm{g} / \mathrm{mL}$ concentration of copper NPs, capacity of reducing highest cupric ions to $\left(\mathrm{Cu}^{2+}\right)$ cuprous ions $\left(\mathrm{Cu}^{+}\right)$is found to be BHA > $\alpha$-tocopherol > copper NP when compared with standards.

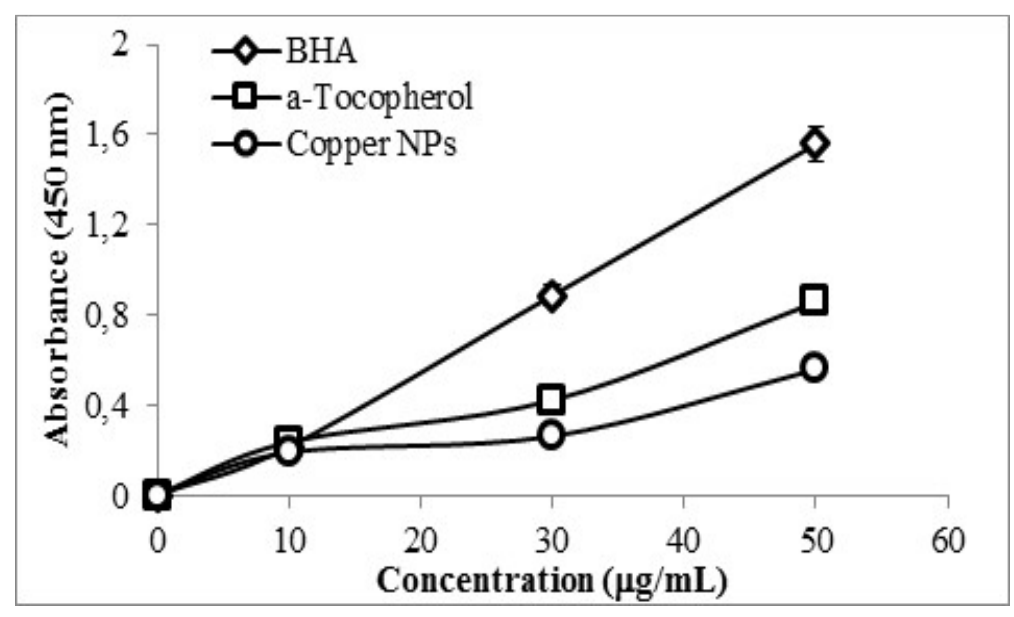

Figure 5. The $\mathrm{Cu}^{2+}-\mathrm{Cu}^{+}$reducing activity of Copper NPs, BHA and $\alpha$-tocopherol at different concentrations $(10-50 \mu \mathrm{g} / \mathrm{mL})$.

\section{Superoxide anion radical scavenging activity}

One of free radicals, superoxide radical is the easiest and most formed oxygen radical by environmental factors and enzymatic and non-enzymatic reactions in the organism. Superoxide anion radicals cause lipid peroxidation. These radicals cause lipid peroxidation and connected deterioration in membrane structure [22]. Besides, superoxide anion radicals can reduce $\mathrm{Fe}^{3+}$ ions to $\mathrm{Fe}^{2+} . \mathrm{Fe}^{2+}$ ions react with Fenton and use hydrogen peroxide to create $\mathrm{OH}$ radicals which are very reactive and cause much structural deterioration. Therefore it is necessary to scavenge superoxide anion radicals in the medium. Standard antioxidant materials' activity to scavenge superoxide anion radical in $50 \mu \mathrm{g} / \mathrm{mL}$ concentration is found to be respectively BHA $>\alpha$ Tocopherol > Copper NPs. These values respectively are $72.3 \pm 0.5>56.4 \pm 1.1>48.3 \pm$ 1.03. When findings are compared with standards, it is observed that copper NPs scavenged superoxide radicals effectively (Figure 6). 
Demirci Gültekin et al., JOTCSA. 2016; 3(3): 623-636.

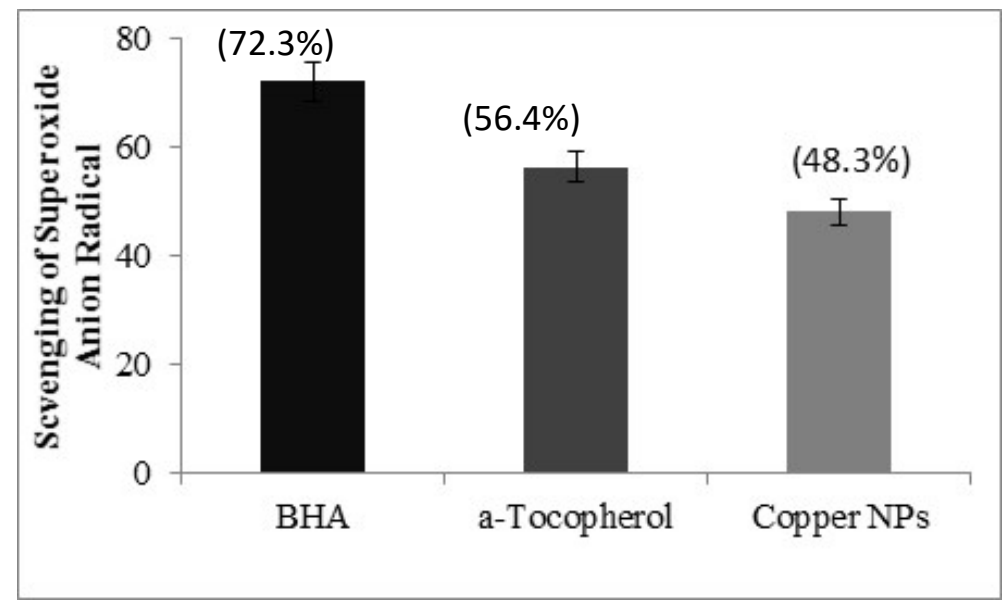

Figure 6. The activity of superoxide anion scavenging of Copper NPs, BHA and $\alpha$-tocopherol at different concentrations $(50 \mu \mathrm{g} / \mathrm{mL})$

\section{The $\mathrm{ABTS}^{\bullet+}$ scavenging activity}

$\mathrm{ABTS}^{\bullet+}$ radical is a colored compound which gives absorbance at $734 \mathrm{~nm}$. ABTS ${ }^{\bullet+}$ radical reacts with antioxidant materials and transfers electron and transforms to non-radical ABTS material. Related material is shown below:

$$
\mathrm{ABTS}^{+\bullet}+\mathrm{A} \rightarrow \mathrm{ABTS}+\mathrm{A}^{+\bullet}
$$

The study used spectrophotometric measurement and followed reducing of absorbance value at $734 \mathrm{~nm}$ and calculate $A B T S^{\bullet+}$ radical scavenging activity. ABTS ${ }^{\bullet+}$ scavenging activity is frequently used in radical scavenging activities of liquid mixtures, drinks, extracts and pure materials [23]. Firstly, standard plot is formed to determine scavenging activity of copper NPs produced with green synthesis and standard antioxidant compounds like BHA and $\alpha$-tocopherol used in study, and $\mathrm{ABTS}^{\bullet+}$ scavenging activities are calculated in all samples using standard plot. ABTS ${ }^{\bullet+}$ scavenging activity of copper NPs is compared with standard BHA and $\alpha$-tocopherol. According to findings, at $50 \mu \mathrm{g} / \mathrm{mL}$ concentration, BHA achieved $73.7 \%$, $\alpha$-tocopherol achieved $79.7 \%$ and copper NPs achieved $85.4 \% \mathrm{ABTS}^{\bullet+}$ radical scavenging activity (Figure 7 ). It was found in this study that copper NPs scavenge $\mathrm{ABTS}^{\circ+}$ radical better than standard antioxidants. 


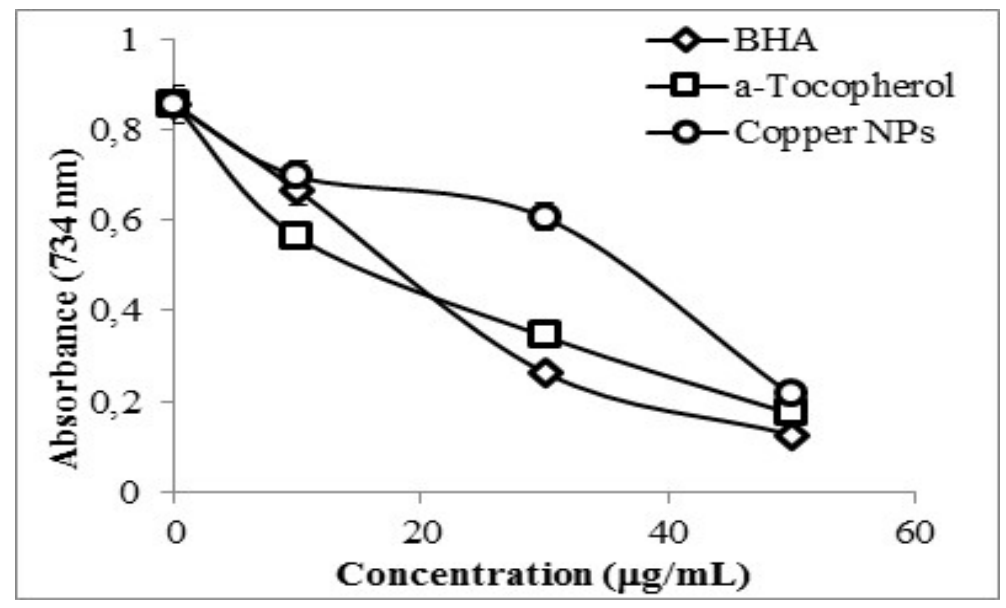

Figure 7. The activity of ABTS radical scavenging of CuO NPs, BHA and $\alpha$-tocopherol at different concentrations $(10-50 \mu \mathrm{g} / \mathrm{mL})$.

\section{Antimicrobial activity of CuO NPs}

In the studies, antibacterial features of CuO NPs which were formed with green synthesis method are determined using spread and culture method which is a simple and fast method on nutrient agar. For this purpose, Pediococcus acidilactici bacteria is applied on agar surface with spread culture method and it is seen that bacteria growth is avoided around disk and diameter of created inhibition is $16.5 \mathrm{~mm}$. The minimum inhibitory concentration (MIC) value was found $\mathrm{Cu}$ NPs $(10 \mu \mathrm{g} / \mathrm{mL})$ using batch method for Pediococcus acidilactici. It is understood that copper NPs connect to cell wall of bacteria, damages its structure and cancels its development [24].

\section{CONCLUSION}

As a result of our examinations, we understood that peroxidase enzyme can be partly purified from fig leaves (Ficus carica) to be used in reaction medium for green synthesis. CuO NPs were characterized using analysis of UV-Vis spectrophotometry, SEM, and XRD. The analysis revealed that the synthesis of CuO NPs and was achieved quantity, direction, and morphology characterization. Manufactured CuO NPs are considered to have been an extensive range of applications in the nanotechnology, the catalyst, pharmaceutical and medical industries. In addition, the experiments showed that CuO NPs have both antimicrobial and antioxidant features. CuO NPs which are acquired with green nano synthesis can be produced more economically and in adequate conditions nontoxic effects on the environment. Besides, examination of electrical and chemical features of acquired CuO NPs can indicate their usage in different areas.

\section{REFERENCES}

1. Hutchison JE. Greener Nanoscience: A Proactive Approach to Advancing Applications and Reducing Implications of Nanotechnology. ACS Nano. 2008 Mar;2(3):395-402. DOI: 10.1021/nn800131j. 
2. Sharma VR, Yngard RA, Lin L. Silver Nanoparticles: Green Synthesis and Their Antimicrobial Activities. Adv. Colloid. Interface Sci. 2009 Jan 30;145(1-2):83-96. DOI: 10.1016/j.cis.2008.09.002.

3. Junjie H. Biosynthesis of SnO2 Nanoparticles by Fig (Ficus Carica) Leaf Extract for Electrochemically Determining $\mathrm{Hg}$ (II) in Water Samples Int. J. Electrochem. Sci. 2015 Nov;10:10668-10676. URL: http://www.electrochemsci.org/papers/vol10/101210668.pdf

4. Liu FK. Analysis and Applications of Nanoparticles in the Separation Sciences: a Case of Gold Nanoparticles. Journal of Chromatography A. 2009 Dec;1216(52):9034-9047. DOI: 10.1016/j.chroma.2009.07.026.

5. Singh DJ, Upadhya MK, Nandelwal NK. Green Synthesis Of Silver Nanoparticles Using Argemonemexicana Leaf Extract And Evaluation Of Their Antimicrobial Activities. Digest Journal of Nanomaterials and Biostructures. 2010 July-Sept;5:483-489. URL:

http://www.chalcogen.ro/483_Singh.pdf

6. Prasoon PS, Chittaranjan B. Green Synthesis of Gold Nanoparticles and Silver Nanoparticles from Leaves and Bark of Ficus Carica for Nanotechnological Applications. International Journal of Scientific and Research Publications. 2012 May;2(5):1-4. URL:

http://citeseerx.ist.psu.edu/viewdoc/download?doi=10.1.1.387.6161\&rep=rep1\&type=pdf.

7. Konishi Y, Ohno K, Saitoh N, Nomura T, Nagamine S, Hishida H, Takahashi Y, Uruga T. Bioreductive deposition of Platinum Nanoparticles on the Bacterium Shewanella algae. J. Biotechnol. 2007 Jun;128(3):648-653. DOI:10.1016/j.jbiotec.2006.11.014.

8. Das SK, Dickinson CF, Lafir DF, Broughamand EM. Synthesis, Characterization and Catalytic Activity of Gold Nanoparticles Biosynthesized with Rhizopus Oryzae Protein Extract Green Chemistry. 2012 Feb;14:1322-1334. DOI:10.1039/c2gc16676c.

9. Abdul Salam HR, Sivarajand R, Venckatesh R. Green Synthesis and Characterization of Zinc Oxide Nanoparticles from Ocimum Basilicum L. Var. Purpurascens Benth.-Lamiaceae Leaf Extract. Materials Letters. 2014 Sept 131(15): 16-18.URL: http://dx.doi.org/10.1016/j.matlet.2014.05.033.

10. Park BK, Jeong S, Kim D, Moon J, Lim S, Kim JS. Synthesis and Size Control of Monodisperse Copper Nanoparticles by Polyol Method. Journal of Colloids and Interface Science. 2007 Mar; 311(2):417-424. DOI: $10.1016 /$ j.jcis.2007.03.039.

11. Han WK, Choi JW, Hwang GH, Hong SJ, Lee JS, Kang SG. Fabrication of Cu Nano Particles by Direct Electrochemical Reduction from Cuo Nano Particles. Applied Surface Science. 2006 Feb;252(8):28322838. URL: http://dx.doi.org/10.1016/j.apsusc.2005.04.049.

12. Zhu HT, Zhang CY, Yin YS. Rapid Synthesis of Copper Nanoparticles by Sodium Hypophosphite Reduction In Ethylene Glycol under Microwave İrradiation. Journal of Crystal Growth. 2004 Oct;270(34):722-728. URL: http://dx.doi.org/10.1016/j.jcrysgro.2004.07.008.

13. Tetsuya K, Oka T, Nagano M, Ishiwata Y, Zheng XG. Synthesis and Application of Stable Copper Oxide Nanoparticle Suspensions for Nanoparticulate Film Fabrication. J. Am. Ceram. Soc. 2007 Jun; 90(1):107-110. DOI: 10.1111/j.1551-2916.2006.01402.x.

14. Etefagh R, Azhir E, Shahtahmasebi N. Synthesis of Cuo Nanoparticles and Fabrication of Nanostructural Layer Biosensors for Detecting Aspergillus niger Fungi. Scientia Iranica. 2013 Jun; 20(3):1055-1058. URL: http://dx.doi.org/10.1016/j.scient.2013.05.015.

15. Phiwdang K, Suphankij S, Mekprasart W, Pecharapa W. Synthesis of CuO Nanoparticles by Precipitation Method Using Different Precursors. Energy Procedia. 2013 June;34:740-745. URL: http://dx.doi.org/10.1016/j.egypro.2013.06.808.

16. Khashan KS, Sulaiman GM, Abdulameer FA. Synthesis and Antibacterial Activity of CuO Nanoparticles Suspension Induced by Laser Ablation in Liquid. Arab J Sci Eng. 2016 Jun 41:301-310. DOI: 10.1007/s13369-015-1733-7.

17. Cicek S, Gungor AA, Adiguzel A, Nadaroglu H. Biochemical Evaluation and Green Synthesis of Nano Silver Using Peroxidase from Euphorbia (Euphorbia amygdaloides) and Its Antibacterial Activity. Journal of Chemistry. 2015 Agust;Article ID:486948,1-7. URL: http: //dx.doi.org/10.1155/2015/486948. 
18. Gungor AA. Use of Different Plant Derived Peroxidases for the Removal of Phenol from Water. Asian Journal of Chemistry. 2011 Jun;23(8):3710-3712. URL:

http://www.asianjournalofchemistry.co.in/User/ViewFreeArticle.aspx?ArticleID=23_8_96.

19. Sharma S, Manhar AK, Bora PJ, Dolui KS, Mandal M. Plasmonic Bulk Heterojunction Photovoltaic Devices Based on Poly (9-Vinylcarbazole)/Gold Nanocomposites: Effect of Aspect Ratio of Gold Nanorod. Journal of Materials Science: Materials in Electronics. 2015;Jul26(7):5465-5474. DOI: 10.1007/s10854-015-3103-3.

20. Abdel-Aziz MS, Shaheen MS, El-Nekeety AA, Abdel-Wahhab MA. Antioxidant and Antibacterial Activity of Silver Nanoparticles Biosynthesized Using Chenopodium Murale Leaf Extract. Journal of Saudi Chemical Society. 2014 Sept; 18(4): 356-363. URL: http://dx.doi.org/10.1016/j.jscs.2013.09.011.

21. Nasrollahzadeh M, Sajadi SM, Vartooni AR. Green synthesis of palladium nanoparticles using Hippophae rhamnoides Linn leaf extract and their catalytic activity for the Suzuki-Miyaura coupling in water. Journal of Molecular Catalysis A: Chemical. 2015 Jun;396:297-303. URL:

http://dx.doi.org/10.1016/j.molcata.2014.10.019.

22. Halliwell B. Establishing the Significance and Optimal Intake of Dietary Antioxidants: The Biomarker Concept. Nutr Rev. 1999 Apr; 57(4):104-113. URL: https://www.ncbi.nlm.nih.gov/pubmed/10228347.

23. Miller NJ, Sampson J, Candeias LP, Bramley PM. Catherine A. Rice-Evans Antioxidant activities of Carotenes and Xanthophylls. FEBS Letters. 1996 Apr;384( 3):240-242. DOI: 10.1016/00145793(96)00323-7.

24. Ruparelia JP, Chatterjee AK, Duttagupta SP, Mukherji S. Strain Specificity in Antimicrobial Activity of Silver and Copper Nanoparticles. Acta Biomaterialia. 2008 May;4(3):707-716. URL:

https://dx.doi.org/10.1016/j.actbio.2007.11.006. 


\section{Türkçe Öz ve Anahtar Kelimeler}

\section{Synthesis of Copper Nanoparticles Using a Different Method: Determination of Their Antioxidant and Antimicrobial Activity}

Demet DEMİRCİ GÜLTEKİN, Azize ALAYLI GÜNGÖR, Hicran ÖNEM, Aynur BABAGİL, Hayrunnisa NADAROĞLU

Öz: Bu çalışmanın amacı, kısmen incir yapraklarından (Ficus carica) saflaştırılmış peroksidaz enzimlerini kullanarak yeşil bir sentez yöntemi üzerinden bakır oksit nanoparçacıklar (CuO NPler) elde etmektir. CuO NPler, gerçekleştirilen deneylerde yeşil sentez yöntemi ile başarı ile sentezlenmiştir. Elde edilen CuO NPlerin morötesi-görünür (UV-Vis) spektrofotometri ile karakteristik özellikleri, ayrıca taramalı elektron mikroskopisi (SEM) ve X-ışını saçılması (XRD) yapılmıştır. Yeşil sentez için en uygun aktifleşme sıcaklığı 30 dakikada gözlenmiştir, pH 8'dir, sıcaklık $25{ }^{\circ} \mathrm{C}^{\prime}$ dir ve $1 \mathrm{mM} \mathrm{CuCl} 2$ kullanılmıştır. Peroksidaz enzimlerinin yeşil sentezde kullanılması ve SEM ve XRD ölçümlerinin sonuçlarına göre CuO NPlerin boyutlarının 50-120 nm arasında olduğu bulunmuştur. Bunun dışında, bu nanoparçacıkların antioksidan ve antibakteriyel özellikleri ölçülmüş ve CuO NPlerinin antioksidan ve antimikrobiyal aktiviteye sahip olduğu bulunmuştur.

Anahtar kelimeler: Bakır nanoparçacıklar; yeşil sentez; peroksidaz.

Sunulma: 22 Temmuz 2016. Düzeltme: 24 Eylül 2016. Kabul: 20 Ekim 2016. 
